\title{
EFFECT OF NPK FERTILIZER AND SOME NATURAL EXTRACT TREATMENTS ON THE CHEMICAL COMPOSTION OF AFRICAN MARIGOLD (TAGETES ERECTA L. VAR. DWARF CHRYSANTHEMUM)
}

\author{
NofAL, E. M. S. ${ }^{1}$ - El-MahrouK, M. E. ${ }^{1}$ - EL-SAYed, B. A. ${ }^{2}-$ RAdWAN, A. M. M. ${ }^{2 *}$ \\ ${ }^{1}$ Hort. Dept., Fac. Agric., Kafrelsheikh Univ., Kafrelsheikh, Egypt \\ ${ }^{2}$ Ornamental Plants Res. Dept., Hort. Res. Inst., ARC, Giza, Egypt \\ *Corresponding author \\ e-mail:annradwan40@gmail.com \\ (Received $3^{\text {rd }}$ Mar 2021; accepted $14^{\text {th }}$ May 2021)
}

\begin{abstract}
This study was conducted in the Nursery of Ornamental Plants Research Department, Horticultural Research Institute, Giza, Egypt, during the growing seasons of 2018 and 2019 to evaluate the influence of NPK fertilization and some natural extracts on the chemical composition of African marigold (Tagetes erecta L. var. dwarf chrysanthemum), using seaweed, Moringa oleifera leaf and dry yeast extracts as a foliar spray at the rate of 0,1 and $2 \mathrm{~g} / \mathrm{l}$ three times separately or in combination with NPK fertilizer at two levels (zero and $2 \mathrm{~g} /$ pot). Results showed that all natural extract treatments recorded significant increase in all chemical constituents studied. The most significant enhancement in this regard was obtained from providing plants with NPK at $2 \mathrm{~g} /$ pot combined with seaweed extract at $2 \mathrm{~g} / \mathrm{l}$ followed by adding it as a sole application and preceded by moringa leaves extract at $2 \mathrm{~g} / \mathrm{l}$ as an interaction treatment with NPK at $2 \mathrm{~g} / \mathrm{pot}$ in elevating $\beta$-carotene pigment content in dry flowers. Meanwhile, the significantly highest records in total phenols percentages was obtained from applying the combination treatment of NPK at $2 \mathrm{~g} / \mathrm{pot}$ with moringa leaves extract at $2 \mathrm{~g} / \mathrm{l}$ followed by the individual application of such extract.
\end{abstract}

Keywords: seaweed, Moringa oleifera extract, dry yeast extract, carotenoids, carbohydrates, $N, P, K, \beta$ carotene

\section{Introduction}

Tagetes erecta L. (African marigold) is one of the most important herbaceous plants in Family Asteraceae. It is an annual ornamental summer plant, native to Mexico. It is used as a bedding plant and in borders of landscape framework, in addition to its function as a space filler and cut flower. From the medical point of view, the leaf extract is good for earache while its paste is used as a remedy for carbuncles, flower extract is considered as blood sterilizer, also it is a good drug for eye disease and ulcers (Bose and Yadav, 1989). It is also used in perfume industry due to containing essential oils in their structure and as an antipathetic to flies. It can be used in foods as a result of its high content of carotenoids (Priyanka et al., 2013). African marigold is highly effective on keeping nematode population under control when cultivating among bulb crops (Caryol, 1960).

Natural extracts act a remarkable role as a natural source of nutrients and growth substances which have a vital turn in enhancing plant chemical composition. Seaweed extract is a natural organic fertilizer elicited from seaweeds which can be classified as a macroscopic, multicultural marine alga that inhibit the coastal regions (Thirumaran et al., 2009a). They contain micro elements (Co, B, Mo, $\mathrm{Zn}, \mathrm{Cu}$ ), auxins, gibberellins and cytokinins (Jensen, 2004), in addition to richness with polysaccharides, macro elements $(\mathrm{N}, \mathrm{P}$ and $\mathrm{K})$ and alginates. Also, millions of tons of seaweed products are used as nutrient 
additives in agriculture and horticulture (Economou et al., 2007). Various investigations have remarked the significant impact of seaweed extracts on micro elements content and photosynthetic pigments compared to control (Gharib et al., 2014). Moringa oleifera belongs to Family Moringaceae is existed commonly in semi-arid and subtropical areas in Africa and tropical Asia to West ward in Egypt and grows in almost all phytogeographical regions as reported by N.R.C. (2006). Moringa leaves extract is a natural source of plant growth regulators (PGRs) such as zeatin cytokinin that plays an essential role in retarding leaf senescence's (Azra et al., 2012). Moringa chloroplast includes high concentration of antioxidants such as ascorbic acid and glutathione that have a vital role in raising plant resistance against oxidative stress (Zulfiquar et al., 2019) in addition to the presence of phenolics in its construction (Foidle et al., 2001). It is also called "Miracle tree" as a result of existing a great deal of fiber, calcium, phosphorus, potassium, sulfer, iron, carotenoids, thiamine, riboflavin, nicotinic acid and complete profile of amino acids in its structure (Bau et al., 1994). Dry yeast extract is considered a neutral origin of cytokinins which enhance cell division and enlargement as well as the synthesis of protein, nucleic acids and B-vitamin. Moreover, it releases $\mathrm{CO}_{2}$ hence improving photosynthesis (Kurzman and Fell, 2005). It contains a wide group of amino acids, vitamins and many nutritional elements i.e., $\mathrm{Na}, \mathrm{Ca}, \mathrm{Fe}, \mathrm{K}, \mathrm{P}, \mathrm{S}, \mathrm{Mg}, \mathrm{Zn}$ and $\mathrm{Si}$ (Nagodawithana, 1991). Nitrogen $(\mathrm{N})$, phosphorus $(\mathrm{P})$ and potassium $(\mathrm{K})$ elements have very important roles in plant growth and development. (N) Plays a vital function in plant constituents' synthesis through the enzymes mode of action (Jones et al., 1991). Moreover, it is existed in nucleic acids which are substantial for protein synthesis and is found in porphyrin structure presented in chlorophyll pigments and cytochromes which are responsible for photosynthetic and respiration process (Dewlin and Witham, 1986). (P) has an important role in energy transfer process as it is a main component in adenosine tri phosphate (ATP), additionally to its position in building of phospholipids (Cho et al., 2000). (K) is very essential for many plant functions such as stomata movement (Krauss and Jiyun, 2000). Moreover, it promotes sugars and carbohydrates translocation through plant sections and has fundamental roles in protein synthesis process (Blevins, 1985).

The main purpose of the study is to investigate effect of using the extracts of seaweed, moringa leaves and dry yeast as a foliar spray and NPK fertilizer (Krystalon of 19:19:19) as a soil drench at different levels on chemical composition of Tagetes erecta L. var. dwarf chrysanthemum to detect the most effective treatments that enhance the maximum chemical composition to decrease chemical fertilizer usage, so support pollution levels reduction.

\section{Materials and methods}

A pot experiment was conducted in Ornamental Plant Research Department, Horticulture Research Institute, Giza Governorate, Egypt during 2017/2018 and 2018/2019 seasons. The aim was to investigate the effect using NPK fertilization at the rate of zero and $2 \mathrm{~g} / \mathrm{pot}$ and spraying seaweed, Moringa oleifera Lam. leaves and dry yeast extracts at concentrations of 0,1 and $2 \mathrm{~g} / \mathrm{l}$ as an individual application or in combination with NPK fertilizer on chemical composition of Tagetes erecta $\mathrm{L}$. var. dwarf chrysanthemum. The obtained seedlings were transplanted on Dec. $6^{\text {th }}$ and $9^{\text {th }}$ in the two seasons, respectively in $14 \mathrm{~cm}$ diameter plastic pot of $12 \mathrm{~cm}$ height filled with a mixture of clay : peatmoss and sand $(1: 1: 1, \mathrm{v} / \mathrm{v} / \mathrm{v})$ as one plant per pot after one month from sowing when the seedling reached 7-10 cm height with 3-4 leaves. The chemical and 
physical composition of the experimental medium showed that the soil texture used in the two seasons was sandy loam. The chemical and physical properties of the growing medium are presented in Table la,b. The analysis was carried out according to the methods described by Cottenie et al. (1982).

Table 1a. Chemical composition of extracted soil sample

\begin{tabular}{|c|c|c|c|c|c|c|c|c|c|c|}
\hline \multicolumn{4}{|c|}{ Cations (meq/l) } & \multicolumn{4}{|c|}{ Anions (meq/l) } & \multirow{2}{*}{ SP } & \multirow{2}{*}{$\begin{array}{c}\mathrm{EC} \\
\mathrm{Ds} / \mathrm{m}\end{array}$} & \multirow{2}{*}{$\begin{array}{c}\mathrm{pH} \\
1: 2.5 \\
\end{array}$} \\
\hline $\mathrm{K}^{+}$ & $\mathrm{Na}^{+}$ & $\mathrm{Mg}^{++}$ & $\mathrm{Ca}^{++}$ & $\mathrm{SO} 4=$ & $\mathrm{Cl}^{-}$ & $\mathrm{HCO}^{-}$ & $\mathrm{CO}=$ & & & \\
\hline 0.9 & 18.1 & 4.8 & 9.2 & 3.2 & 28.5 & 1.1 & - & 37.00 & 3.3 & 7.99 \\
\hline
\end{tabular}

Table 1b. Physical properties of the used soil

\begin{tabular}{c|c|c|c|c}
\hline \multirow{2}{*}{ Texture } & \multicolumn{4}{|c}{ Soil particles \% } \\
\cline { 2 - 5 } & clay & silt & Sweet sand & Rough sand \\
\hline Loamy sand & 7.3 & 15.3 & 40.4 & 37.0 \\
\hline
\end{tabular}

The treatments of this study were performed as follows:

Control (tap water); Seaweed extract at 1 and $2 \mathrm{~g} / \mathrm{l}$; Moringa leaves extract at 1 and $2 \mathrm{~g} / \mathrm{l}$; yeast extract at 1 and $2 \mathrm{~g} / \mathrm{l}$; Seaweeds extract at 1, $2 \mathrm{~g} / \mathrm{l}+2 \mathrm{~g} \mathrm{NPK/pot;} \mathrm{Moringa}$ leaves extract at 1 and $2 \mathrm{~g} / \mathrm{l}+2 \mathrm{~g}$ NPK/pot, Yeast extract at 1 and $2 \mathrm{~g} / \mathrm{l}+2 \mathrm{~g} \mathrm{NPK} /$ pot, $2 \mathrm{~g} \mathrm{NPK}$.

\section{Experimental design}

The experiment layout was a factorial in complete randomized design. The treatments were replicated three times including three plants in each replicate and one plant in each pot representing NPK treatments the main factor and the natural extract treatments the sub-factor.

\section{Preparation of the natural extracts}

1- Seaweed extract prepared by dissolving $1 \mathrm{gm}$ and $2 \mathrm{gm}$ of a commercial product containing some biostimulant ingredients such as vitamins, free amino acids, hormones and alginates processed out of elected seaweeds (Sargassum sp.; Ascophythum nodosum and Luminaria sp.) in one liter of tap water obtaining 2 concentrations ( 1 and $2 \mathrm{~g} / \mathrm{l}) \mathrm{using}$ tap water as a control treatment.

2- Moringa eaxtract intended by mixing 1 and $2 \mathrm{~g}$ of Moringa oleifera leaves powder after collecting from a certain mature mother tree, dried in a shaded place and ground in an electrical grinder with tap water, then the extracts were shaken for 4 hours by shaker and kept in dark place for 24 hours then the extract was filtered through a filter paper.

3- Active dry yeast extracts prepared by melting specific weights ( 1 and $2 \mathrm{~g}$ ) of commercial product in one liter of tap water and adding sugar at ratio $(1: 1, \mathrm{~g} / \mathrm{g})$. The obtained solution was kept 24 hours in a dark warm place before use.

4- Chemical fertilizer a solution prepared by dissolving $2 \mathrm{gm}$ of the commercial product (Kristalon) as NPK fertilizer (19:19:19) in one liter of tap water.

The preceding natural extracts were utilized as a foliar spray individually or in combination with NPK fertilizer (Kristalon) at concentration of $2 \mathrm{~g} / \mathrm{pot}$ applied as a soil 
drench (20 $\mathrm{ml}$ for each pot) either alone or combined with the above-mentioned extracts. The treatments were thrice applied; the first one was after 15 days from transplanting followed by two fortnightly intervals.

\section{Data recorded after the end of the two seasons on Jan $22^{\text {nd }}$ and $25^{\text {th }}$, respectively were:}

Photosynthetic pigments: chlorophyll a, b and carotenoids were determined in samples taken from a certain leaf in the middle part of the plant according to the method explained by Wellburn and Lichtenthaler (1984) and measured by using spectrophotometer at 665 , 649 and $470 \mathrm{~nm}$ wavelength, respectively.

$\beta$-carotene pigment was estimated in dry flowers petals according to A.O.A.C. (1995).

Total carbohydrates (\%) were evaluated colorimetrically in dry leaves, applying the method recommended by Dubois et al. (1956).

$N, P$ and $K(\%)$ estimation: total nitrogen percentage was evaluated in dry samples using micro-Kjeldahle method according to Jackson (1973), phosphorus percentage was colorimetrically determined as explained by Cottenie et al. (1982) and potassium percentage was estimated by using flame photometer set according to Jackson (1973).

Total indoles \% were determined in the methanolic extract, using P. Dimethyl Amino Benzaldehyde test "Erlich regeant" according to the method recommended by Larsen et al. (1962).

Total phenols \% evaluated by extracting the phenolic compounds according to the method illustrated by Diaz and Martin (1972).

\section{Statistical analysis}

Analysis of variances was performed and comparisons among means of treatments were performed using the new multiple range test at the 5\% level of significance as described by Duncan (1955) and Steel et al. (1997), using SAS program (1994) and the new multiple range.

\section{Results}

\section{Effect of NPK and some natural treatments on some chemical composition characteristics of African marigold}

Chlorophyll $a, b$ and carotenoids in the leaves

Data presented in Table 2 indicated that applying NPK at $2 \mathrm{~g} /$ pot succeeded to give the significantly highest leaves content of chlorophyll a, b and carotenoids compared to control plants $(0.00 \mathrm{~g}$ NPK $)$ in both seasons. Regarding the effect of some natural extracts, data in the same Table cleared that all treatments significantly increased leaves content of carotenoids over control $(0.00 \mathrm{~g}$ natural extract $)$ in the two seasons. The significantly highest values of chlorophyll $\mathrm{a}, \mathrm{b}$ and carotenoids resulted from spraying plants with seaweed extract at $2 \mathrm{~g} / \mathrm{l}$ followed by plants which received seaweed extract at $1 \mathrm{~g} / \mathrm{l}$ with the notability of moringa leaves extract at $2 \mathrm{~g} / \mathrm{l}$ in this concern. In the connection of the interaction treatments data showed that the significantly most effective treatment resulted from the treatment of NPK at $2 \mathrm{~g} /$ pot combined with seaweed extract at $2 \mathrm{~g} / \mathrm{l}$ followed by the treatment of NPK at $2 \mathrm{~g} /$ pot combined with seaweed extract at $1 \mathrm{~g} / \mathrm{l}$, occupying the second rank in this concern and preceded by zero NPK combined with seaweed extract at $2 \mathrm{~g} / \mathrm{l}$ in increasing carotenoids content in both seasons when compared to control. 
Table 2. Effect of NPK and some natural extracts on chlorophyll $a, b$ and carotenoids $(\mathrm{mg} / \mathrm{g} f . \mathrm{w}$.$) in the leaves as well as \beta$ carotene contents in the flowers of Tagetes erecta L. var. dwarf chrysanthemum during two seasons

\begin{tabular}{|c|c|c|c|c|c|c|c|c|c|c|c|c|}
\hline \multirow{4}{*}{$\begin{array}{c}\text { Parameters } \\
\text { Fertilizers } \\
\begin{array}{c}\text { Natural extracts } \\
(\mathrm{g} / \mathrm{l})\end{array}\end{array}$} & \multicolumn{3}{|c|}{ Chlorophyll a (mg/g f.w.) } & \multicolumn{3}{|c|}{ Chlorophyll b (mg/g f.w.) } & \multicolumn{3}{|c|}{ Carotenoids (mg/g f.w.) } & \multicolumn{3}{|c|}{$\beta$-Carotene (mg/g d.w.) } \\
\hline & \multicolumn{3}{|c|}{ NPK (A) } & \multicolumn{3}{|c|}{ NPK (A) } & \multicolumn{3}{|c|}{ NPK (A) } & \multicolumn{3}{|c|}{ NPK (A) } \\
\hline & $0.00 \mathrm{~g}$ & $2.00 \mathrm{~g}$ & Mean (B) & $0.00 \mathrm{~g}$ & $2.00 \mathrm{~g}$ & Mean (B) & $0.00 \mathrm{~g}$ & $2.00 \mathrm{~g}$ & Mean (B) & $0.00 \mathrm{~g}$ & $2.00 \mathrm{~g}$ & Mean $(B)$ \\
\hline & \multicolumn{12}{|c|}{ First season } \\
\hline Control & $0.400 \mathrm{k}$ & $0.484 \mathrm{~h}$ & $0.442 \mathrm{~F}$ & $0.150 \mathrm{~g}$ & $0.160 f g$ & $0.155 \mathrm{E}$ & $0.250 \mathrm{i}$ & $0.262 \mathrm{hi}$ & $0.256 \mathrm{G}$ & $0.256 \mathrm{~h}$ & $0.265 \mathrm{~h}$ & $0.261 \mathrm{D}$ \\
\hline Seaweed $1 \mathrm{~g}$ & $0.675 d$ & $0.752 b$ & $0.713 \mathrm{~B}$ & $0.271 b c$ & $0.286 \mathrm{ab}$ & $0.279 \mathrm{~B}$ & $0.459 \mathrm{e}$ & $0.562 \mathrm{c}$ & $0.510 \mathrm{~B}$ & $0.402 \mathrm{e}$ & $0.596 \mathrm{ab}$ & 0.499B \\
\hline Seaweed $2 \mathrm{~g}$ & $0.707 \mathrm{c}$ & $0.863 \mathrm{a}$ & $0.785 \mathrm{~A}$ & $0.284 \mathrm{ab}$ & $0.298 \mathrm{a}$ & $0.291 \mathrm{~A}$ & $0.598 b$ & $0.696 \mathrm{a}$ & $0.647 \mathrm{~A}$ & $0.504 \mathrm{c}$ & $0.607 \mathrm{a}$ & $0.556 \mathrm{~A}$ \\
\hline Moringa $1 \mathrm{~g}$ & $0.426 \mathrm{j}$ & $0.525 f$ & $0.475 \mathrm{D}$ & $0.260 \mathrm{c}$ & $0.270 \mathrm{bc}$ & $0.265 \mathrm{C}$ & $0.310 \mathrm{~g}$ & $0.435 \mathrm{e}$ & $0.372 \mathrm{D}$ & $0.318 \mathrm{f}$ & $0.490 \mathrm{~cd}$ & $0.404 \mathrm{C}$ \\
\hline Moringa $2 \mathrm{~g}$ & $0.465 \mathrm{i}$ & $0.607 \mathrm{e}$ & $0.536 \mathrm{C}$ & $0.269 b c$ & $0.279 b$ & $0.274 \mathrm{BC}$ & $0.404 \mathrm{f}$ & $0.504 d$ & $0.454 \mathrm{C}$ & $0.463 d$ & $0.563 b$ & $0.513 \mathrm{~B}$ \\
\hline Yeast $1 \mathrm{~g}$ & $0.424 \mathrm{j}$ & $0.497 \mathrm{gh}$ & $0.461 \mathrm{E}$ & $0.168 \mathrm{ef}$ & $0.181 \mathrm{de}$ & $0.174 \mathrm{D}$ & $0.271 \mathrm{hi}$ & $0.290 \mathrm{gh}$ & $0.281 \mathrm{~F}$ & $0.269 \mathrm{gh}$ & $0.284 \mathrm{f}-\mathrm{h}$ & $0.277 \mathrm{D}$ \\
\hline Yeast $2 \mathrm{~g}$ & $0.421 \mathrm{j}$ & $0.502 \mathrm{~g}$ & $0.462 \mathrm{E}$ & $0.171 \mathrm{~d}-\mathrm{f}$ & $0.188 \mathrm{~d}$ & $0.180 \mathrm{D}$ & $0.290 \mathrm{gh}$ & $0.396 f$ & $0.343 \mathrm{E}$ & $0.267 \mathrm{gh}$ & $0.303 \mathrm{fg}$ & $0.285 \mathrm{D}$ \\
\hline \multirow[t]{2}{*}{ Mean $(\mathrm{A})$} & $0.503 \mathrm{~B}$ & $0.604 \mathrm{~A}$ & & $0.225 \mathrm{~B}$ & $0.238 \mathrm{~A}$ & & $0.369 \mathrm{~B}$ & $0.449 \mathrm{~A}$ & & $0.354 \mathrm{~B}$ & $0.444 \mathrm{~A}$ & \\
\hline & \multicolumn{12}{|c|}{ Second season } \\
\hline Control & $0.413 \mathrm{~h}$ & $0.500 \mathrm{f}$ & $0.457 \mathrm{~F}$ & $0.151 \mathrm{~g}$ & $0.161 f g$ & $0.156 \mathrm{D}$ & $0.251 \mathrm{~h}$ & $0.261 \mathrm{~h}$ & $0.256 \mathrm{G}$ & $0.251 \mathrm{~h}$ & $0.267 \mathrm{gh}$ & $0.259 \mathrm{E}$ \\
\hline Seaweed $1 \mathrm{~g}$ & $0.607 d$ & $0.744 b$ & $0.675 \mathrm{~B}$ & $0.270 \mathrm{bc}$ & $0.288 \mathrm{ab}$ & $0.279 \mathrm{AB}$ & $0.461 d$ & $0.562 b$ & $0.512 \mathrm{~B}$ & $0.403 \mathrm{e}$ & $0.591 \mathrm{ab}$ & $0.497 \mathrm{~B}$ \\
\hline Seaweed $2 \mathrm{~g}$ & $0.705 \mathrm{c}$ & $0.842 \mathrm{a}$ & $0.773 \mathrm{~A}$ & $0.281 \mathrm{ab}$ & $0.296 \mathrm{a}$ & $0.288 \mathrm{~A}$ & $0.571 \mathrm{~b}$ & $0.686 \mathrm{a}$ & $0.628 \mathrm{~A}$ & $0.508 \mathrm{c}$ & $0.624 \mathrm{a}$ & $0.566 \mathrm{~A}$ \\
\hline Moringa $1 \mathrm{~g}$ & $0.464 \mathrm{~g}$ & $0.570 \mathrm{e}$ & $0.517 \mathrm{D}$ & $0.257 \mathrm{c}$ & $0.271 b c$ & $0.264 \mathrm{~B}$ & $0.385 \mathrm{e}$ & $0.444 d$ & $0.415 \mathrm{D}$ & $0.319 \mathrm{f}$ & $0.491 \mathrm{~cd}$ & $0.405 \mathrm{C}$ \\
\hline Moringa $2 \mathrm{~g}$ & $0.518 \mathrm{f}$ & $0.607 d$ & $0.563 \mathrm{C}$ & $0.269 b c$ & $0.279 \mathrm{ab}$ & $0.274 \mathrm{AB}$ & $0.401 \mathrm{e}$ & $0.502 \mathrm{c}$ & $0.452 \mathrm{C}$ & $0.461 \mathrm{~d}$ & $0.567 b$ & $0.514 \mathrm{~B}$ \\
\hline Yeast $1 \mathrm{~g}$ & $0.419 \mathrm{~h}$ & $0.521 \mathrm{f}$ & $0.470 \mathrm{~F}$ & $0.168 \mathrm{e}-\mathrm{g}$ & $0.180 \mathrm{de}$ & $0.174 \mathrm{C}$ & $0.271 \mathrm{gh}$ & $0.306 f$ & $0.289 \mathrm{~F}$ & $0.278 \mathrm{gh}$ & $0.275 \mathrm{gh}$ & $0.276 \mathrm{DE}$ \\
\hline Yeast $2 \mathrm{~g}$ & $0.449 \mathrm{~g}$ & $0.549 \mathrm{e}$ & $0.499 \mathrm{E}$ & $0.173 d-f$ & $0.189 \mathrm{~d}$ & $0.181 \mathrm{C}$ & $0.295 f g$ & $0.398 \mathrm{e}$ & $0.346 \mathrm{E}$ & $0.269 \mathrm{gh}$ & $0.299 \mathrm{fg}$ & $0.284 \mathrm{D}$ \\
\hline Mean (A) & $0.511 \mathrm{~B}$ & $0.619 \mathrm{~A}$ & & $0.224 \mathrm{~B}$ & $0.238 \mathrm{~A}$ & & $0.376 \mathrm{~B}$ & $0.451 \mathrm{~A}$ & & $0.356 \mathrm{~B}$ & $0.445 \mathrm{~A}$ & \\
\hline
\end{tabular}

Within a column means having the same letter are not significantly different at $5 \%$ level, according to Duncan's multiple range test 


\section{$\beta$-carotene in flowers}

Data presented in Table 1. showed that the highest flower content of $\beta$-carotene was found in plants provided with NPK at $2 \mathrm{~g} /$ pot as compared to control plants ( $0.00 \mathrm{~g} \mathrm{NPK})$ that recorded the lowest values in this regard. With respect to the effect of some natural extracts, data revealed that all treatments significantly raised flower content of $\beta$-carotene over control ( $0.00 \mathrm{~g}$ natural extract) in both seasons. Treating plants with seaweed extract at $2 \mathrm{~g} / \mathrm{l}$ proved its mastery in this respect followed by the treatment of moringa leaves extract at $2 \mathrm{~g} / \mathrm{l}$ with significant differences in between. Referring to the effect of the interaction between NPK and natural extract treatments, data clarified that the significantly highest values of $\beta$-carotene were complementary to plants which received NPK at $2 \mathrm{~g} /$ pot combined with seaweed extract at $2 \mathrm{~g} / \mathrm{l}$ followed by the treatment of NPK at $2 \mathrm{~g} / \mathrm{pot}$ in combination with seaweed extract at $1 \mathrm{~g} / \mathrm{l}$ with significant differences in between in both seasons.

\section{Total carbohydrates, nitrogen $(N)$, phosphorus $(P)$ and potassium $(K)$ percentage $(\%)$}

Total carbohydrates

Data exhibited in Table 3 showed that fertilizing the plants with NPK at 2 g/pot gave the highest total carbohydrates percentage in the leaves when compared to untreated plants in both seasons. Concerning the effect of some natural extracts, data in the same Table demonstrated that all treatments gave significantly more values than control in both seasons. The most significant positive influence resulted from spraying the plant with seaweeds extract at $2 \mathrm{~g} / \mathrm{l}$ followed by seaweeds extract at $1 \mathrm{~g} / \mathrm{l}$, occupying the second rank in this regard with the supremacy of moringa leaves extract at $2 \mathrm{~g} / \mathrm{l}$ in both seasons. Respecting the effect of the interaction between NPK and natural extract treatments, data indicated that treating the plants with NPK at $2 \mathrm{~g} /$ pot combined with seaweed extract at $2 \mathrm{~g} / \mathrm{l}$ succeeded to score the significantly utmost high values of total carbohydrate percentage. The second rank was belonged to plants fertilized with NPK at $2 \mathrm{~g} /$ pot combined with seaweed extract at $1 \mathrm{~g} / \mathrm{l}$ with the superiority of moringa leaves extract at $2 \mathrm{~g} / \mathrm{l}$ without significant differences between such two treatments in the first season.

\section{$\mathrm{N}, \mathrm{P}$ and $\mathrm{K}$ percentage}

Data presented in the same Table, revealed that significantly highest record of nitrogen $(\mathrm{N} \%)$, phosphorus $(\mathrm{P} \%)$ and potassium $(\mathrm{K} \%)$ in the leaves was belonged to plants which gained the highest dose of NPK at $2 \mathrm{~g} /$ pot when compared to control plants in both seasons. Regarding the effect of some natural extracts, data remarked that all treatments induced $\mathrm{N}$, $\mathrm{P}$ and $\mathrm{K} \%$ over control in both seasons. Treating plants with seaweeds extract at $2 \mathrm{~g} / \mathrm{l}$ proved its predominance followed by plants provided with seaweeds extract at $1 \mathrm{~g} / \mathrm{l}$ without significant differences between using seaweed extract $1 \mathrm{~g} / \mathrm{l}$ and moringa leaves extract at 2 $\mathrm{g} / \mathrm{l}$ in elevating $\mathrm{P} \%$ in the second season, with the superiority of moringa leaves extract at 2 $\mathrm{g} / \mathrm{l}$ in raising the three macro-elements in both seasons. Referring to the effect of the interaction between NPK and natural extract treatments, data showed that the treatment of NPK at $2 \mathrm{~g} /$ pot combined with seaweed extract at $2 \mathrm{~g} / \mathrm{l}$ occupied the first position in this concern. The second rank in increasing N \% was confined to plants supplied with NPK at 2 $\mathrm{g} /$ pot combined with seaweed extract at $1 \mathrm{~g} / \mathrm{l}$, while the treatment of zero NPK combined with seaweeds extract at $2 \mathrm{~g} / \mathrm{l}$ categorized the second rank in raising $\mathrm{P} \%$ and $\mathrm{K} \%$ in both seasons. The remainder treatments recorded significantly lower values but higher than control. 
Table 3. Effect of NPK and some natural extracts on total carbohydrates, $N, P$ and $K(\%)$ in the leaves of Tagetes erecta L. var. dwarf chrysanthemum during two seasons

\begin{tabular}{|c|c|c|c|c|c|c|c|c|c|c|c|c|}
\hline Parameters & \multicolumn{3}{|c|}{ Total carbohydrates $(\%)$} & \multicolumn{3}{|c|}{$\mathbf{N}(\%)$} & \multicolumn{3}{|c|}{$\mathbf{P}(\%)$} & \multicolumn{3}{|c|}{$\mathrm{K}(\%)$} \\
\hline Fertilizers & \multicolumn{3}{|c|}{ NPK (A) } & \multicolumn{3}{|c|}{ NPK (A) } & \multicolumn{3}{|c|}{ NPK (A) } & \multicolumn{3}{|c|}{ NPK (A) } \\
\hline \multirow{2}{*}{$\begin{array}{c}\text { Natural extracts } \\
(\mathrm{g} / \mathrm{l})\end{array}$} & $0.00 \mathrm{~g}$ & $2.00 \mathrm{~g}$ & Mean $(B)$ & $0.00 \mathrm{~g}$ & $2.00 \mathrm{~g}$ & Mean (B) & $0.00 \mathrm{~g}$ & $2.00 \mathrm{~g}$ & Mean (B) & $0.00 \mathrm{~g}$ & $2.00 \mathrm{~g}$ & Mean (B) \\
\hline & \multicolumn{12}{|c|}{ First season } \\
\hline Control & $26.18 \mathrm{j}$ & $26.89 \mathrm{i}$ & $26.53 \mathrm{G}$ & $1.16 \mathrm{i}$ & $1.78 \mathrm{e}$ & $1.47 \mathrm{~F}$ & $0.171 \mathrm{i}$ & $0.214 \mathrm{i}$ & $0.192 \mathrm{E}$ & $1.23 \mathrm{~h}$ & $1.32 \mathrm{~g}$ & $1.28 \mathrm{~F}$ \\
\hline Seaweed $1 \mathrm{~g}$ & $30.03 \mathrm{e}$ & $32.11 \mathrm{~b}$ & $31.07 \mathrm{~B}$ & $1.83 \mathrm{e}$ & $2.73 b$ & $2.28 \mathrm{~B}$ & $0.552 \mathrm{de}$ & $0.651 b c$ & $0.601 \mathrm{~B}$ & $1.60 \mathrm{c}$ & $1.64 \mathrm{bc}$ & $1.62 \mathrm{~B}$ \\
\hline Seaweed $2 \mathrm{~g}$ & $31.34 \mathrm{c}$ & $33.71 \mathrm{a}$ & $32.53 \mathrm{~A}$ & $1.90 \mathrm{e}$ & $2.94 \mathrm{a}$ & $2.42 \mathrm{~A}$ & $0.692 b$ & $0.792 \mathrm{a}$ & $0.742 \mathrm{~A}$ & $1.71 \mathrm{ab}$ & $1.78 \mathrm{a}$ & $1.74 \mathrm{~A}$ \\
\hline Moringa $1 \mathrm{~g}$ & $28.14 \mathrm{~g}$ & $31.43 \mathrm{c}$ & $29.78 \mathrm{D}$ & $1.51 \mathrm{fg}$ & $2.51 \mathrm{c}$ & $2.01 \mathrm{CD}$ & $0.449 \mathrm{fg}$ & $0.552 \mathrm{de}$ & $0.501 \mathrm{C}$ & $1.41 \mathrm{f}$ & $1.52 \mathrm{de}$ & $1.46 \mathrm{D}$ \\
\hline Moringa $2 \mathrm{~g}$ & $29.30 \mathrm{f}$ & $32.19 \mathrm{~b}$ & $30.74 \mathrm{C}$ & $1.62 \mathrm{f}$ & $2.58 \mathrm{c}$ & $2.10 \mathrm{C}$ & $0.499 \mathrm{ef}$ & $0.596 \mathrm{~cd}$ & $0.548 \mathrm{BC}$ & $1.49 \mathrm{e}$ & $1.59 \mathrm{~cd}$ & $1.54 \mathrm{C}$ \\
\hline Yeast $1 \mathrm{~g}$ & $27.37 \mathrm{~h}$ & $30.48 d$ & $28.93 \mathrm{~F}$ & $1.34 \mathrm{~h}$ & $2.35 \mathrm{~d}$ & $1.85 \mathrm{E}$ & $0.326 \mathrm{~h}$ & $0.435 f g$ & $0.381 \mathrm{D}$ & $1.32 \mathrm{~g}$ & $1.40 \mathrm{f}$ & $1.36 \mathrm{E}$ \\
\hline Yeast $2 \mathrm{~g}$ & $27.73 \mathrm{~h}$ & $30.78 d$ & $29.26 \mathrm{E}$ & $1.45 \mathrm{gh}$ & $2.45 \mathrm{~cd}$ & $1.95 \mathrm{D}$ & $0.363 \mathrm{gh}$ & $0.486 \mathrm{ef}$ & $0.425 \mathrm{D}$ & $1.40 \mathrm{fg}$ & $1.45 \mathrm{ef}$ & $1.42 \mathrm{D}$ \\
\hline \multirow[t]{2}{*}{ Mean (A) } & $28.58 \mathrm{~B}$ & $31.08 \mathrm{~A}$ & & $1.54 \mathrm{~B}$ & $2.48 \mathrm{~A}$ & & $0.436 \mathrm{~B}$ & $0.532 \mathrm{~A}$ & & $1.45 \mathrm{~B}$ & $1.53 \mathrm{~A}$ & \\
\hline & \multicolumn{12}{|c|}{ Second season } \\
\hline Control & $26.26 \mathrm{j}$ & $26.98 \mathrm{i}$ & $26.62 \mathrm{G}$ & $1.17 \mathrm{j}$ & $1.88 \mathrm{f}$ & $1.53 \mathrm{~F}$ & $0.175 \mathrm{i}$ & $0.226 \mathrm{i}$ & $0.201 \mathrm{E}$ & $1.23 \mathrm{~h}$ & $1.36 \mathrm{~g}$ & $1.29 \mathrm{E}$ \\
\hline Seaweed $1 \mathrm{~g}$ & $31.04 \mathrm{~d}$ & $33.27 \mathrm{~b}$ & $32.15 \mathrm{~B}$ & $1.73 \mathrm{~g}$ & $2.66 \mathrm{~b}$ & 2.19B & $0.543 \mathrm{de}$ & $0.642 \mathrm{bc}$ & $0.593 \mathrm{~B}$ & $1.61 \mathrm{~b}-\mathrm{d}$ & $1.70 \mathrm{a}-\mathrm{c}$ & $1.65 \mathrm{~B}$ \\
\hline Seaweed $2 \mathrm{~g}$ & $32.37 \mathrm{c}$ & $34.77 \mathrm{a}$ & $33.57 \mathrm{~A}$ & $2.00 \mathrm{f}$ & $2.89 \mathrm{a}$ & $2.44 \mathrm{~A}$ & $0.691 \mathrm{ab}$ & $0.723 \mathrm{a}$ & $0.707 \mathrm{~A}$ & $1.71 \mathrm{ab}$ & $1.80 \mathrm{a}$ & $1.76 \mathrm{~A}$ \\
\hline Moringa $1 \mathrm{~g}$ & $29.17 f$ & $31.36 \mathrm{~d}$ & $30.26 \mathrm{D}$ & $1.41 \mathrm{i}$ & $2.45 \mathrm{~cd}$ & $1.93 \mathrm{D}$ & $0.415 \mathrm{~g}$ & $0.519 \mathrm{e}$ & $0.467 \mathrm{C}$ & $1.48 \mathrm{ef}$ & $1.54 \mathrm{de}$ & $1.51 \mathrm{C}$ \\
\hline Moringa $2 \mathrm{~g}$ & $30.30 \mathrm{e}$ & $32.37 \mathrm{c}$ & $31.33 \mathrm{C}$ & $1.53 \mathrm{~h}$ & $2.53 \mathrm{c}$ & $2.03 \mathrm{C}$ & $0.493 \mathrm{ef}$ & $0.596 \mathrm{~cd}$ & $0.545 \mathrm{~B}$ & $1.49 \mathrm{ef}$ & $1.59 \mathrm{c}-\mathrm{e}$ & $1.54 \mathrm{C}$ \\
\hline Yeast $1 \mathrm{~g}$ & $28.11 \mathrm{~h}$ & $30.44 \mathrm{e}$ & $29.27 \mathrm{~F}$ & $1.24 \mathrm{j}$ & $2.26 \mathrm{e}$ & $1.75 \mathrm{E}$ & $0.309 \mathrm{~h}$ & $0.422 \mathrm{fg}$ & $0.366 \mathrm{D}$ & $1.31 \mathrm{gh}$ & $1.40 \mathrm{fg}$ & $1.36 \mathrm{E}$ \\
\hline Yeast $2 \mathrm{~g}$ & $28.79 \mathrm{~g}$ & $30.58 \mathrm{e}$ & $29.69 \mathrm{E}$ & $1.40 \mathrm{i}$ & $2.33 \mathrm{de}$ & $1.87 \mathrm{D}$ & $0.371 \mathrm{gh}$ & $0.495 \mathrm{ef}$ & $0.433 \mathrm{C}$ & $1.38 f g$ & $1.48 \mathrm{ef}$ & $1.43 \mathrm{D}$ \\
\hline Mean (A) & $29.43 \mathrm{~B}$ & $31.39 \mathrm{~A}$ & & $1.50 \mathrm{~B}$ & $2.42 \mathrm{~A}$ & & $0.428 \mathrm{~B}$ & $0.518 \mathrm{~A}$ & & $1.46 \mathrm{~B}$ & $1.55 \mathrm{~A}$ & \\
\hline
\end{tabular}

Within a column means having the same letter are not significantly different at $5 \%$ level, according to Duncan's multiple range test 


\section{Total indoles and phenols}

Data presented in Table 4 demonstrated that the significantly highest percentage of total indoles was obtained due to applying NPK at $2 \mathrm{~g} /$ pot which showed a clear reduction in such constituent in both seasons. Dealing with some natural extracts, data showed that all treatments scored significantly higher values than control in the two seasons. The significantly highest record in the leaves was concomitant to plants supplied with seaweeds extract at $2 \mathrm{~g} / \mathrm{l}$ followed by plants which gained seaweeds extract at $1 \mathrm{~g} / \mathrm{l}$ with significant differences in between. Concerning the effect of the interaction between NPK and natural extracts, data cleared that the significantly highest indoles percentage in the leaves was concurrent to plants which received NPK at $2 \mathrm{~g} /$ pot in combination with seaweed extract at $2 \mathrm{~g} / \mathrm{l}$. The second rank was belonged to plants provided with either zero NPK combined with seaweed extract at $2 \mathrm{~g} / \mathrm{l}$ in the first season or those treated with NPK at $2 \mathrm{~g} /$ pot combined with seaweed extract at $1 \mathrm{~g} / \mathrm{l}$ in the second one. The remainder treatments gave less values than control. Regarding total phenols percentage, data exhibited in the same Table showed that supplying the plants with either NPK at $2 \mathrm{~g} / \mathrm{pot}$ or those untreated (control) recorded the same position without significant differences in between in both seasons.

Table 4. Effect of NPK and some natural extracts on total indoles and total phenols (\%) of Tagetes erecta L. var. dwarf chrysanthemum during two seasons

\begin{tabular}{|c|c|c|c|c|c|c|}
\hline Parameters & \multicolumn{3}{|c|}{ Total indoles (\%) } & \multicolumn{3}{|c|}{ Total phenols (\%) } \\
\hline Fertilizers & \multicolumn{3}{|c|}{ NPK (A) } & \multicolumn{3}{|c|}{ NPK (A) } \\
\hline \multirow{2}{*}{$\begin{array}{c}\text { Natural extracts } \\
(\mathrm{g} / \mathrm{l})\end{array}$} & $0.00 \mathrm{~g}$ & $2.00 \mathrm{~g}$ & Mean (B) & $0.00 \mathrm{~g}$ & $2.00 \mathrm{~g}$ & Mean (B) \\
\hline & \multicolumn{6}{|c|}{ First season } \\
\hline Control & 0.601 & $0.68 \mathrm{k}$ & $0.64 \mathrm{G}$ & $0.017 \mathrm{e}-\mathrm{g}$ & $0.022 \mathrm{e}-\mathrm{g}$ & $0.019 \mathrm{CD}$ \\
\hline Seaweed $1 \mathrm{~g}$ & $2.01 \mathrm{~d}$ & $3.32 \mathrm{c}$ & $2.66 \mathrm{~B}$ & $0.008 \mathrm{~g}$ & $0.012 \mathrm{fg}$ & $0.010 \mathrm{DE}$ \\
\hline Seaweed $2 \mathrm{~g}$ & $3.49 \mathrm{~b}$ & $4.07 \mathrm{a}$ & $3.78 \mathrm{~A}$ & $0.028 \mathrm{~d}-\mathrm{f}$ & $0.031 \mathrm{de}$ & $0.030 \mathrm{C}$ \\
\hline Moringa $1 \mathrm{~g}$ & $0.69 \mathrm{k}$ & $1.40 \mathrm{~h}$ & $1.05 \mathrm{~F}$ & $0.045 \mathrm{~cd}$ & $0.059 \mathrm{bc}$ & $0.052 \mathrm{~B}$ \\
\hline Moringa $2 \mathrm{~g}$ & $0.72 \mathrm{k}$ & $1.53 \mathrm{~g}$ & $1.13 \mathrm{E}$ & $0.075 \mathrm{ab}$ & $0.082 \mathrm{a}$ & $0.078 \mathrm{~A}$ \\
\hline Yeast 1g & $0.82 \mathrm{j}$ & $1.63 \mathrm{f}$ & $1.23 \mathrm{D}$ & $0.005 \mathrm{~g}$ & $0.008 \mathrm{~g}$ & $0.007 \mathrm{E}$ \\
\hline Yeast $2 \mathrm{~g}$ & $1.00 \mathrm{k}$ & $1.74 \mathrm{e}$ & $1.37 \mathrm{C}$ & $0.010 \mathrm{fg}$ & $0.015 \mathrm{e}-\mathrm{g}$ & $0.012 \mathrm{DE}$ \\
\hline \multirow[t]{2}{*}{ Mean (A) } & $1.33 \mathrm{~B}$ & $2.05 \mathrm{~A}$ & & $0.027 \mathrm{~A}$ & $0.033 \mathrm{~A}$ & \\
\hline & \multicolumn{6}{|c|}{ Second season } \\
\hline Control & $0.69 \mathrm{~m}$ & 0.911 & $0.80 \mathrm{G}$ & $0.018 \mathrm{ef}$ & $0.023 \mathrm{ef}$ & $0.020 \mathrm{CD}$ \\
\hline Seaweed $1 \mathrm{~g}$ & $2.01 \mathrm{~d}$ & $3.31 \mathrm{~b}$ & $2.66 \mathrm{~B}$ & $0.009 \mathrm{f}$ & $0.014 \mathrm{ef}$ & $0.011 \mathrm{DE}$ \\
\hline Seaweed $2 \mathrm{~g}$ & $2.92 \mathrm{c}$ & $4.01 \mathrm{a}$ & $3.47 \mathrm{~A}$ & $0.028 \mathrm{e}$ & $0.031 \mathrm{de}$ & $0.029 \mathrm{C}$ \\
\hline Moringa $1 \mathrm{~g}$ & 0.991 & $1.41 \mathrm{i}$ & $1.20 \mathrm{~F}$ & $0.046 \mathrm{~cd}$ & $0.059 \mathrm{bc}$ & $0.053 \mathrm{~B}$ \\
\hline Moringa 2g & $1.20 \mathrm{k}$ & $1.51 \mathrm{~h}$ & $1.35 \mathrm{E}$ & $0.072 \mathrm{ab}$ & $0.084 \mathrm{a}$ & $0.078 \mathrm{~A}$ \\
\hline Yeast $1 \mathrm{~g}$ & $1.30 \mathrm{j}$ & $1.61 \mathrm{~g}$ & $1.46 \mathrm{D}$ & $0.005 \mathrm{f}$ & $0.008 \mathrm{f}$ & $0.007 \mathrm{E}$ \\
\hline Yeast $2 \mathrm{~g}$ & $1.69 \mathrm{f}$ & $1.90 \mathrm{e}$ & $1.80 \mathrm{C}$ & $0.010 \mathrm{f}$ & $0.016 \mathrm{ef}$ & $0.013 \mathrm{DE}$ \\
\hline Mean (A) & $1.55 \mathrm{~B}$ & $2.10 \mathrm{~A}$ & & $0.027 \mathrm{~A}$ & $0.034 \mathrm{~A}$ & \\
\hline
\end{tabular}

Within a column means having the same letter are not significantly different at $5 \%$ level, according to Duncan's multiple range test

Referring to the effect of some natural extracts, data reported that the most effective treatment in decreasing total phenols percentage in the leaves was belonged to plants which received yeast extract at $1 \mathrm{~g} / \mathrm{l}$, followed by plants treated with either seaweed 
extract at $1 \mathrm{~g} / \mathrm{l}$ or those supplied with yeast extract at $2 \mathrm{~g} / \mathrm{l}$ without significant differences in between in both seasons. However, the treatments of moringa leaves extract at $2 \mathrm{~g} / \mathrm{l}$ significantly increased phenols level followed by moringa leaves extract at $1 \mathrm{~g} / \mathrm{l}$ with significant differences in all cases in both seasons. Respecting the interaction between NPK and natural extract treatments, data indicate that supplying plants with either NPK at $2 \mathrm{~g} /$ pot combined with yeast extract at $1 \mathrm{~g} / \mathrm{l}$ or those deprived from NPK and treated with yeast extract at $1 \mathrm{~g} / 1$ only occupied the first rank in reducing total phenols percentage in the leaves. Meanwhile, the plants which received NPK at $2 \mathrm{~g} /$ pot combined with moringa leaves extract at $2 \mathrm{~g} / \mathrm{l}$ proved its mastery in raising such constituent followed by those which gained the same extract at the same level without applying NPK at g/pot when compared with control treatment without NPK and natural extracts which recorded lower values of phenols than moringa extract treatments in both seasons.

\section{Discussion}

The previous results of some chemical composition characteristics i.e., chlorophyll pigments in the leaves, $\beta$-carotene pigment in the flowers, total carbohydrates, $\mathrm{N}, \mathrm{P}$ and $\mathrm{K} \%$, in the leaves as well as indoles and phenols $\%$, in the two seasons of this study revealed that NPK at $2 \mathrm{~g} /$ pot and its interaction with seaweed extract at its two levels led to the significantly utmost influence in this concern in most cases followed by moringa leaves extract which had a positive effect on all chemical traits except for phenols $\%$. This may be due to the inductive impact of NPK on chemical composition characters. Nitrogen is a main constituent of protein and is considered as a fundamental ingredient of protoplasm which increases the chlorophyll contents in leaves (Parmer, 2007a,b). Phosphorus is a very essential element for producing adenosine tri-phosphate (ATP) which is involved in many chemical processes in plants and carbohydrates metabolism (Razaq et al., 2017). Potassium is a very important agent in enhancing carbohydrate synthesis and its translocation (Belorkar, 1992) as well as NPK fertilization acts a vital role in inducing pigments accumulation e.g. $\beta$-carotene (Aziz and Ebraheem, 2009). The previous findings are in accordance with those indicated by Hassan (2016) on chamomile plant who mentioned that applying NPK fertilizer increased chlorophyll a and $b$, carotenoids, total carbohydrates contents as well as $\mathrm{N}, \mathrm{P}$ and $\mathrm{K} \%$. Moreover, AlMohammad and Al-Zorfy (2012) found that supplying Tagetes erecta L. with NPK at $8 \mathrm{~g} /$ pot increased $\beta$-carotene content in flowers. Concerning the significant improvement obtained from applying seaweeds extract may be due to its effect on reducing chlorophyll degradation as a result of existing betains in its composition (Whapham et al., 1993). A gradual increase in $\beta$-carotene was observed from applying seaweeds extract as this may be based on its potenancy in encouraging treated plants to accumulate photosynthetic pigments (Kusnetsov et al., 1994). The significant increase in total carbohydrates \% in the leaves may be attributed to its positive influence on chlorophyll accumulation which reflected on photosynthesis rates and eventually carbohydrates production (Emam, 2016). The significantly highest scores in minerals ( $\mathrm{N}, \mathrm{P}$ and $\mathrm{K} \%$ ) was noticed as a result of using seaweeds extract and this may be attributed to existence of many inductive components in its structure i.e., auxins, cytokinins and minerals which motivate the vital processes in plants and enhance stomata uptake performance (Mancuso et al., 2006). The obtained results are in accordance with those revealed by Sridhar and Rengasamy (2010) on Tagetes erecta L., Emam (2016) on Calendula officinalis and Tagetes erecta L. who found that spraying seaweed extract significantly increased total carbohydrates 
percentages in the leaves. Abdou et al. (2018) reported that supplying Gladiolus grandiflorus (Peter Pears) with seaweed extract at $3 \mathrm{~cm}^{3} / 1$ lead to the significantly highest chemical constituent content. The advanced rank, which was occupied by moringa leaves extract in elevating chemical constituents, may be due to the presence of zeutin in its construction which involved in suppressing senescence, in addition to its beneficial role in forcing plant to precocity of cytokinin synthesis resulting in more photosynthetic pigments formation (Ali et al., 2011). Furthermore, it consists of high levels of calcium, potassium and ascorbic acid which resulted in $\mathrm{Na}^{+}$ions level reduction and $\mathrm{K}^{+}$as well as $\mathrm{Ca}^{+}$ions level induction which are connected with carotenoids scale growing in plants (Zaki and Rady, 2015). The promoted effect of moringa leaves extract on $\beta$-carotene content in plants may be due to that it is an excellent source of $\beta$-carotene (Liu et al., 2007; Ferreira et al., 2008). The photosynthetic pigments findings confirm with the results reported by Abdalla (2013) on Ruca vesicaria sub sp. sativa and Soliman et al. (2015) on Atrocorpus heterophyllus Lam. who revealed that moringa leaves extract foliar application improved photosynthetic pigments. Moreover, Britton (2009) reported that moringa leaves extract is a rich source of carorenoids pigment (Lutein, $\beta$-carotene and zeaxanthin). Occupying moringa leaves extract the second rank after seaweed extract in raising carbohydrates percentage in the leaves may be attributed to its positive role in stimulating photosynthetic pigments accumulation, leading to enhancement of photosynthesis and uptake processes in plants with high rates which resulted in raising total carbohydrates content (Ahmed, 2017), in addition to its remarkable role in regulating genes expression which are responsible for metabolic processes (Hebers and Sonnewald, 1998). The motivation effect of moringa leaves extract on $\mathrm{N}, \mathrm{P}$ and $\mathrm{K}$ accumulation in the leaves might be due to the entity of zeatin, calcium, magnesium and other growth in gradients. Therefore, it acts as natural growth enhancer (Azra et al., 2012). The aforementioned results are in accordance with Soliman et al. (2015) on Atrocarpus heterophyllus Lam. and Abd-Elkafie et al. (2016) on Coriandrum sativum who stated that applying moringa leaves extract enhanced total carbohydrates, N, P and K \%, in the leaves. Also Desoky et al. (2019) indicated that maximum values of photosynthetic pigments, photochemical activity, RNA and DNA as well as total carbohydrates were obtained when supplying Sorghum vulgore L. with moringa leaves extracts. Barsoom (2021) mentioned that treating Hymenocallis speciosa with moringa extract at 5\% resulted in the highest value of carbohydrates in bulbs. Concerning the inductive effect of moringa leaves extract on elevating total phenols \% in the leaves may be due to the presence of different phenolic compounds in its structure (Nascimento et al., 2017). Hence, alleviated the promotive effects on chemical constituents characteristics. The previous results matched with those reported by Abdalla (2013) on rocket plants and Ali et al. (2018) on Pelargonium graveolens L. Herit. who mentioned that spraying the plants with moringa extract gave a significant increase in phenolic content of plants.

\section{Conclusion}

It could be recommended to supply plants with NPK at $2 \mathrm{~g} /$ pot combined with seaweed extract at $2 \mathrm{~g} / \mathrm{l}$ to gain the significantly highest constituent values especially $\beta$ - carotene in the flowers as a colorant agent in food preservatives. The superiority of moringa leaves extract treatments was observed in elevating chemical composition in plants in most cases, while resulted in the significant increment in phenols percentage, explaining the mitigation of the simulative effect on such constituents compared with this resulted from 
seaweeds extract. Hence the NPK dose was sustained by the stimulators as proved to be must and this needs a future work to increase the stimulators doses.

\section{REFERENCES}

[1] Abdalla, M. M. (2013): The potential of Moringa oleifera extract as a biostimulant in enhancing the growth, biochemical and hormonal contents in rocket (Eruca vesicaria sub sp.sativa) plants. - Int. J. Plant Physiol. Biochem. 5(3): 42-49.

[2] Abd-ElKafie, O. M., Sidky, M. M., Kasem, M. M., Abd-ElBaki, Sh. M. (2016): Improving the vegetative growth and chemical contents of coriander (Coriandrum sativum L.) plant by using Moringa leaf extract. - Mansoura Univ., J. Plant Prod. 7(12): 1357-1363.

[3] Abdou, M. A. H., Badran, F. S., Ahmed, E. T., Taha, R. A., Abdel-Mola, M. A. M. (2018): Effect of compost and some natural stimulant treatments on II corms production and chemical constituents of Gladiolus grandiflorus cv. Peter Pears plants. - Scientific J. Flowers \& Ornamental plants 5(2): 115-126.

[4] Ahmed, M. M. (2017): Effect of Moringa oleifera leaf extract on growth, metabolites and antioxidant system of barley plant. - J. Environ. Studies. Res. 6(E2): 260-271.

[5] Ali, Z., Maqsood, S., Basra, A., Munir, H., Mahmood, A., Yousaf, S. (2011): Mitigation of drought stress in maize by natural and synthetic growth promoters. - J. Agric. Soc. Sci. 7(2): 56-62.

[6] Ali, E. F., Hassan, F. A. S., El-Gimabi, M. (2018): Improving the growth, yield and volatile oil content of Pelargonium graveolens L. Herit by foliar application with moringa leaf extract through motivating physiological and biochemical parameters. - South Afr. J. Bot. 119(4): 383-389.

[7] Al-Mohammad, M. H. S., Al-Zorpy, M. T. H. (2012): Effect of NPK fertilizer and spraying with putrescine on growth, flowering and flowers content of some active constituents for Tagetes erecta_L. - Basrah J. Agric. Sci. 25(4): 948-958.

[8] A.O.A.C. (1995): Association of Official Chemists, Official Methods of Analysis. $-15^{\text {th }}$ ed., Washington, DC.

[9] Aziz, N. K., Ebraheem, E. R. (2009): Influence of agrotonic fertilizer, magnetized water and planting date on growth, flowering and some carotenoids pigments in marigold. - Iraq J. Agric. Sci. 40(2): 134-147.

[10] Azra, Y., Basra, S. M. A., Ahmed, R., Wahid, A. (2012): Performance of late sown wheat in response to foliar application of Moringa oleifera Lam. leaf extract. - Chil. J. Agric.Res. 72(1): 92-97.

[11] Barsoom, M. A. (2021): Comparative study on the effect of organic, bio, chemical fertilization and natural extracts on Hymenocallis speciosa response to salinity tolerance. Int. J. Environ. 10(1): 47-65.

[12] Bau, H. M., Villaume, C., Lin, C. F., Evrard, J., Quemener, B., Nicolas, J. P., Mejean, L. (1994): Effect of solid state fermentation using Rhizopus oligasporus sp. T-3 on elimination of ant nutritional substances and modification of biochemical constituents of defatted rapeseed meal. - J. Science of Food and Agriculture 65(3): 315-322.

[13] Belorkar, P. V., Patel, B. N., Golliwar, V. J., Kothare, A. J. (1992): Effect of nitrogen in spacing on growth, flowering and yield of African marigold. - J. Soils and Crops 2: 62-64.

[14] Blevins, D. G. (1985): Role of potassium in protein metabolism in plants. - In: Munson, R. D. (ed.) Potassium in Agriculture. ASA-CSSA-SSSA in 1986.

[15] Bose, T. K., Yadav, L. P. (1989): Commercial Flowers. - Naya Prakash, Calcutta, India, $874 p$.

[16] Britton, G. (2009): Carotenoids in food. - Carotenoids 1B: 45-66.

[17] Caryol, J. C. (1960): Rev. Hort. Paris 139: 2276. 
[18] Cho, Y-H., Park, E-A., Chiang, M-H. (2000): Effect of nitrogen from nutrient solution on the growth of Aster tataricus, Chystanthemum boreale and Fradugium japonicum. Korean J. Hort. Sci. Technol. 18(1): 14-17.

[19] Cottenie, A., Verllo, M., Kiekan, L., Velghe, G., Comerynck, R. (1982): Chemical Analysis of Plants and Soils. Laboratory of Analytical and Agrochemistry. - State Univ., GhentBelgium, pp. 44-45.

[20] Desouky, E., Merwad, A. R., Ibrahim, S. (2019): Humus materials and Moringa (Moringa oleifera Lam.) leaf extract modulate the harmful effect of soil salinity stress in Sudan grass (Sorghum vulgare L.). - Egypt J. Agron. 1: 29-45.

[21] Dewlin, R. M., Witham, F. H. (1986): Plant Physiology. - PWS Publishers, A division of Wadsworth, Inc., Boston, USA.

[22] Diaz, D. H., Martin, G. C. (1972): Peach seed dormancy in relation to endogenous inhibitors and applied growth substances. - J. Amer. Society. Hortic. Sci. 97: 651-654.

[23] Dubois, M., Gilles, K. A., Hamilton, J. K., Rebers, P. T., Smith, F. (1956): Colorimetric method for determination of sugars and related substances. - Analytical Chemistry 28(3): 350-356.

[24] Duncan, D. B. (1955): Multiple range and multiple F. test. - J. Biometrics 11: 1-42.

[25] Economou, G., Lyra, D., Sotirakoglou, K., Fasseas, K., Taradilis, P. (2007): Stimulating Orobanche ramose seed germination with Ascophyllum nodosum extract. - Phytoparasitica Hort. Sci. 22: 473-475.

[26] Emam, T. M. (2016): Effect of application of seaweed extracts on growth and quality of some ornamental plants. - M.Sc. Thesis, Fac. Agric., Ain Shams, Univ. Egypt.

[27] Ferreira, P. M. P., Farias, D. F., de Abreu Oliveira, J. T., de Fátima Urano Carvalho, A. (2008): Moringa oleifera: bioactive compound and nutritional potential. - Rev. Nutr. 21(4): 431-437.

[28] Foidle, N., Makkar, H. P. S., Beeker, K. (2001): The potential of Moringa oleifera for agricultural and industrial. - In: Fuglie, L. J. (eds.) The Miracle Tree. Multipurpose Attributes of Moringa, 45-76 Wageningen, Netherlands.

[29] Gharib, F., Zeid, I., Salem, O., Ahmed, E. (2014): Effect of Sargassum latifolium extract on growth, oil content and enzymatic activities of rosemary plants under salinity stress. Life Sci. J. 11(10): 933-945.

[30] Hassan, R. H. T. (2016): Studies on the effect of some bio stimulants on Matricaria chamomilla, Mentha longfolia and Artemisia abrotanum. - Ph.D. Thesis, Fac. of Agric., Kafr-El-Sheikh Univ., Egypt.

[31] Hebers, K., Sannewald, V. (1998): Altered gene expression: brought about by inter and pathogen interactions. - J. Plant. Res. 111: 323-328.

[32] Jackson, M. L. (1973): Soil Chemical Analysis. - Prentice-Hall of India Private Limited M-97, New Delhi, India, 498p.

[33] Jensen, E. (2004): Seaweeds. Fact or fancy. - Published by Moses the Midwest Organic and Sustainable Education, From the Broad Caster 12(30): 164-170.

[34] Jones, I. B., Wolf, B., Milles, H. A. (1991): Plant Analysis Hand Book. - Macro-Micro Publishing. Inc., 213p.

[35] Krauss, A., Jiyun, J. (2000): Strategies for improving balanced fertilization. - Inter. Pot Tamarind Seed Gum Inst., Basel Switzerland.

[36] Kurzman, C. P., Fell, J. W. (2005): Biodiversity and Eco physiology of Yeasts. - In: Rosa, C. A., Gábor, P. (eds.) Yeast Hand book. Springer. Verlag Berlin and Heidelberg Gmb $\mathrm{H} \& \mathrm{Co} . \mathrm{KG}$.

[37] Kusnetsov, V., Oelmueller, R., Sarwat, M. I., Porfirora, S. A., Cherepneva, G. N., Hermann, R., Kulaeva, O. N. (1994): Cytokinin, abscisic acid and light-affect accumulation of chloroplast proteins in Lupinus luteus cotyledons without notable effect on steady-state mRNA levels. - Planta 194: 318-327.

[38] Larsen, P., Harbor, A., Klungsour, S., Asheim, T. (1962): On the biogenesis of some indole compounds in Acetobacter xylinum. - Physiologia Plantarum 15(3): 552-565. 
[39] Liu, Y., Perera, C. O., Suresh, V. (2007): Comparison of three chosen vegetables with others from South East Asia for their lutein and Zeaxanthin content. - Food Chem. 101: 1533-1539.

[40] Mancuso, S., Azzarello, E., Mugnai, S., Briand, X. (2006): Marine bioactive substances (IPA extract) improve foliar ion uptake and water tolerance in potted Vitis vinifera plants. - Advances in Horticultural Science 20: 156-161.

[41] Nagodawithana, W. T. (1991): Yeast Technology. - Foods Corporation Pup. By Van Nostrand Rein Vold. New York, USA, 273p.

[42] NRC (2006): Last Crops of Africa, Vol. II. Vegetables Tables. - The National Academies Press, Washington DC.

[43] de Oliveira do Nascimento, K., Reis, I. P., Augusta, I. M. (2017): Total phenolic and antioxidant capacity of flower, leaf and seed of Moringa oleifera. - Int. J. Food and Nut. Res. (IJFNR) 1(1): 1-6.

[44] Parmer, Y. S. (2007a): Effect of nitrogen, phosphorus and bio fertilizer application on plant growth and bulb production in tuberose. - Haryana J. Hortic. Sci. 36(1-2): 82-85.

[45] Parmer, Y. S. (2007b): Influence of bio fertilizers, nitrogen and phosphorus application on flower quality in tuberose (Polianthes tuberosa L.) cv. Double. - Haryana J. Hortic. Sci. 36(3-4): 273-276.

[46] Priyanka, D., Shalini, T., Navneet, V. K. (2013): A brief study in marigold Tagetes erecta. - J. Pharmacy 4(1): 43-48.

[47] Razaq, M., Zhang, P., Shen, H-L., Salahuddin (2017): Influence of nitrogen and phosphorus on the growth and root morphology of Acer mono. - PLoS One 12(2): e0171321.

[48] SAS program (1994): SASSISTAT USER'S GUIDE. - Statistics. Vers. 6.04.4 ${ }^{\text {th }}$ Ed., SAS Institute Inc., Cary. N. C., U.S. A.

[49] Soliman, A. S., Sarhan, A. M. Z., Nabih, A., Gomma, S. A., Hosain, E. A. (2015): Response if Atrocarpvs heterophllus Lam. to some natural extracts at the early growth stages. 2chemical constituents of the plants. - Scient J. Flowers \& Ornam. Plants 2(2): 193-201.

[50] Sridhar, S., Rengasamy, R. (2010): Studies on the effect of seaweeds liquid fertilizer on the flowering plant Tagetes erecta in field trial. - Advances in Biores. 1: 29-34.

[51] Steel, R. G. D., Torri, J. H., Dickey, D. A. (1997): Principles and Procedures of Statistics: A Biometrical Approach. $-3^{\text {rd }}$ ed. Mc Graw-Hill, NewYork.

[52] Thirumaran, G., Arumugarn, M., Arumugam, R., Anantharaman, P. (2009a): Effect of seaweed liquid fertilizer on growth and pigment concentration of Cyamopsis tetrogonolaba L. Taub. - Amer. Eur. J. Agron. 2(2): 50-56.

[53] Wellburn, A. R., Lichtenthaler, H. (1984): Formula and program to determine total carotenoids and chlorophylls-a and b of leaf extracts in different solvents. - Adv. Agricul. Biotechn. 2(1): 9-12.

[54] Whapham, C. A., Blundern, G., Jenkins, T., Hankins, S. D. (1993): Significance of betaines in the increased chlorophyll content of plants treated with seaweed extract. - J. Appl. Phycol. 5: 231-234.

[55] Zaki, S., Rady, M. (2015): Moringa oleifera leaf extract improves growth, physiochemical attributes, antioxidant defence system and yields of salt-stressed Phaseolus vulgaris L. plants. - Res. Gate 8: 120-134.

[56] Zulfiquar, F., Casadesus, A., Brockman, H., Munne-Bosch, S. (2019): An overview of plant-based natural biostimulants for sustainable horticulture with a particular focus on moringa leaf extracts. - Plant Sci. 295: 110194. 